\title{
Ketebalan Tunika Intima dan Media Arteri Karotis Komunis pada Karsinoma Nasofaring Pra dan Pascaradioterapi
}

\author{
Ferryan Sofyan, ${ }^{1}$ Dindy Samiadi, ${ }^{2}$ Bogi Soeseno, ${ }^{2}$ M. Thaufiq Boesoirie, ${ }^{2}$ Lina Lasminingrum ${ }^{2}$ \\ ${ }^{1}$ Rumah Sakit Haji Adam Malik Medan, ${ }^{2}$ Departemen Ilmu Kesehatan Telinga Hidung Tenggorok- \\ Bedah Kepala Leher Fakultas Kedokteran Universitas Padjadjaran-RS Dr. Hasan Sadikin Bandung
}

\begin{abstract}
Abstrak
Radioterapi eksternal merupakan pengobatan utama karsinoma nasofaring. Radioterapi eksternal menyebabkan disfungsi endotel arteri karotis komunis yang menurunkan produksi nitrogen oksida dan prostasiklin di sel endotel sehingga terjadi penebalan dinding pembuluh darah. Tujuan penelitian ini untuk mengetahui perubahan ketebalan intima media dan diameter lumen arteri karotis komunis akibat radioterapi eksternal pada penderita karsinoma nasofaring. Tipe penelitian adalah studi deskriptif dengan rancangan pre-post design. Penelitian dilakukan di Departemen Telinga Hidung Tenggorok-Bedah Kepala Leher-Rumah Sakit Dr. Hasan Sadikin Bandung mulai Maret 2009-Februari 2010. Pada penelitian ini dilakukan pemeriksaan ultrasonografi gray scale praradioterapi, pascaradioterapi, dan 10 minggu pascaradioterapi. Hasil penelitian ini menggunakan uji Fischer dan T berpasangan. Terdapat 25 subjek karsinoma nasofaring dan hasil penelitian ditemukan peningkatan ketebalan intima media sebesar 0,1 mm di intima media arteri karotis komunis kanan dan 0,09 $\mathrm{mm}$ di intima media arteri karotis komunis kiri $(\mathrm{p}<0,001)$, juga ditemukan pengurangan diameter lumen arteri karotis komunis kanan sebesar 0,384 mm dan $0,342 \mathrm{~mm}$ di arteri karotis komunis kiri $(\mathrm{p}<0,001)$. Simpulan, radioterapi eksternal menunjukkan ketebalan intima media dan pengurangan diameter lumen arteri karotis komunis pada penderita karsinoma nasofaring. [MKB. 2012;44(3):179-85].
\end{abstract}

Kata kunci: Diameter lumen, karsinoma nasofaring, ketebalan intima media, radioterapi eksternal

\section{Intima and Media Tunica Thickness of Common Carotid Artery in Nasopharyngeal Carcinoma Pre and Post External Radiotherapy}

\begin{abstract}
External radiotherapy is the main treatment for nasopharyngeal carcinoma. External radiotherapy can cause endothelial dysfunction of common carotid artery and reduces nitrogen oxide and prostacyclin by endothelial cell and cause thickening of the vessels walls. Purpose of this study was to find out changes in intima-media thickness and lumen diameter of common carotid artery due to radiotherapy in patients with nasopharyngeal carcinoma. This research was descriptive with pre and post design and performed from March 2009 to February 2010 in the Ear Nose Throat-Head Neck Surgery Department of Dr. Hasan Sadikin Hospital Bandung. Gray scale ultrasound examination was performed before, after and ten weeks after radiotherapy and calculated by using Fischer's test and paired T test. They were 25 subjects and was found out $0.1 \mathrm{~mm}$ additional thickness in right intima media and $0.09 \mathrm{~mm}$ in left intima media common carotid artery $(\mathrm{p}<0.001)$, also found reduction in lumen diameter of common carotid artery in which $0.384 \mathrm{~mm}$ in the right and $0.342 \mathrm{~mm}$ in the left $(\mathrm{p}<0.001)$. In conclusions, external radiotherapy can cause increase intima media thickness and reduction lumen diameter in common carotid artery in patients with nasopharyngeal carcinoma. [MKB. 2012;44(3):179-85].
\end{abstract}

Key words: External beam irradiation, intima media thickness, lumen diameter, nasopharyngeal carcinoma

Korespondensi: Ferryan Sofyan, dr., Rumah Sakit Haji Adam Malik Medan, jalan Bungan Lau 17 Medan Tuntungan Km.

12,mobile08126506407,e-mail dr.ferrysofyan@yahoo.com 


\section{Pendahuluan}

Karsinoma nasofaring (KNF) merupakan tumor yang sumbernya berasal dari sel-sel epitel yang melapisi permukaan nasofaring. ${ }^{1}$ Karsinoma ini termasuk keganasan yang jarang terjadi di sebagian negara di dunia. Jumlah kasus mencapai $2 \%$ dari seluruh karsinoma sel skuamosa kepala dan leher dengan insidensi $0,5-2$ per 100.000 di Amerika, namun kasus ini endemik di negara seperti China Selatan, Asia Tenggara, Jepang, Timur Tengah/Afrika Utara. Telah dilaporkan bahwa karsinoma ini merupakan keganasan yang paling umum ketiga dengan kejadian 50/100.000 di provinsi Guangdong Cina Selatan. Insidensi karsinoma nasofaring di Departemen Telinga Hidung Tenggorok-Bedah Kepala Leher (THTKL) RS Dr. Cipto Mangunkusumo tahun 19952000 sebanyak $49,7 \%{ }^{3}$ dan di bagian THT-KL RS Dr. Hasan Sadikin (RSHS) Bandung pada tahun 2001-2005 sebanyak $25,3 \%{ }^{4}$

Pilihan utama terapi karsinoma nasofaring menggunakan radioterapi, khususnya karsinoma nasofaring yang tidak berdiferensiasi (World Health Organization/WHO tipe III) oleh karena bersifat radiosensitif. Radioterapi ini bertujuan untuk mematikan sel-sel tumor tanpa merusak struktur jaringan yang normal di sekitarnya. Pada radioterapi dosis tinggi dan fraksinasi yang besar mempunyai konsekuensi efek samping yang makin besar pula. Pada stadium I dan II, pemberian radioterapi untuk tujuan kuratif, sedangkan pada stadium III dan IV pemberian kombinasi radioterapi akan mengurangi respons terapinya. ${ }^{5}$

Radioterapi dapat mengakibatkan kerusakan kelenjar ludah, mukosa rongga mulut, kulit, saraf, tulang, otot, dan pembuluh darah. ${ }^{5}$ Komplikasi lain akibat radioterapi yaitu aterosklerosis sistem pembuluh darah. Aterosklerosis yang terbentuk akibat radioterapi merupakan risiko penyempitan pada arteri karotis komunis. ${ }^{6}$

Radioterapi akan menyebabkan kerusakan sel endotel sehingga terjadi disfungsi endotel. ${ }^{7}$ Kerusakan sel endotel pembuluh darah diikuti fibrosis tunika media disertai perdarahan lokal dan terjadi nekrosis. ${ }^{8}$ Pada pemeriksaan jaringan pembuluh darah didapatkan perubahan patologi seperti proliferasi tunika intima dengan atau tanpa ateromatosis, trombosis. ${ }^{9}$

Pada penelitian yang dilakukan Gianicolo dkk., ${ }^{6}$ dinyatakan terjadi peningkatan ketebalan lapisan intima media arteri karotis komunis pada penderita yang telah mendapat radioterapi di leher 2,9 tahun lalu. Radioterapi di leher merupakan faktor predisposisi untuk aterosklerosis. Barubaru ini, radiasi di leher dihubungkan dengan penebalan dinding pembuluh darah, mempercepat pembentukan plak aterosklerosis dan stenosis arteri koroner. Penelitian terbaru menemukan bahwa radiasi pada leher penderita Hodgkin dan non-Hodgkin meningkatkan risiko ketebalan lapisan intima media arteri menjadi lebih besar bila dibandingkan dengan kontrol. ${ }^{6}$

Alat yang dipergunakan untuk radioterapi eksternal di Subbagian Radioterapi RSHS yaitu pesawat Tele Cobalt merk Xin Hua Co60 FCC 8.000 yang mempunyai kemampuan penetrasi ke jaringan tumor hingga mencapai $20 \mathrm{~cm}$ dan kemampuan aktivitas sampai 8.000 curie. Dosis per fraksi 180-200 cGy per hari diberikan lima kali per minggu dengan dosis total 6.600-7.000 cGy selama 6,5-7 minggu. ${ }^{10}$

Arteri karotis komunis yang melintas di leher bagian lateral berpotensi terkena paparan sinar radiasi jika penyinaran dilakukan dari arah lateral. Pembuluh darah bersifat sangat radiosensitif sehingga efek radiasi tidak langsung membentuk radikal bebas yang akan mengakibatkan apoptosis sel endotel..$^{11}$ Pemberian radioterapi dengan dosis minimal 3.500-4.400 cGy dapat menyebabkan kerusakan pada lapisan endotel arteri karotis sehingga terjadi disfungsi endotel yang memicu aterosklerosis. ${ }^{12}$ Lesi awal aterosklerosis akan terus berkembang, yang mengakibatkan terjadi penyempitan. Bila penyempitan arteri karotis komunis yang terjadi semakin meningkat akan mengurangi aliran darah ke otak dan menimbulkan gejala serebrovaskular, seperti yang telah disebut sebelumnya. ${ }^{6}$ Lesi awal aterosklerosis diketahui dengan mengukur ketebalan intima media (intima media thickness/IMT) arteri karotis komunis. Nilai normal IMT yaitu $<0,8 \mathrm{~mm}$ dan bila nilai IMT $\geq 0,8 \mathrm{~mm}$, hal ini menandakan telah terjadi lesi awal aterosklerosis. ${ }^{13}$

American Heart Association (AHA) telah merekomendasikan penggunaan ultrasonografi untuk deteksi proses pembentukan aterosklerosis. Jenis ultrasonografi terbaik yang dipergunakan untuk mendapatkan gambaran awal terjadinya aterosklerosis dan mengukur IMT pada arteri karotis komunis yaitu bright mode gray scale ultrasonography. ${ }^{13}$ Tujuan penelitian ini untuk mengetahui perubahan ketebalan tunika dan diameter lumen arteri akibat radioterapi eksternal pada penderita karsinoma nasofaring.

\section{Metode}

Desain penelitian ini adalah studi deskriptif dengan rancangan penelitian pre-post design pada subjek penelitian yang dipilih secara konsekutif sampling untuk mengetahui pengaruh radioterapi eksternal sebagai penyebab penebalan dinding dan penyempitan lumen arteri karotis komunis pada 
kelompok penderita karsinoma nasofaring yang akan mendapat radioterapi. Penelitian dilakukan pada bulan Maret 2009 sampai Februari 2010 di Departemen THT-KL dan Departemen Radiologi RS Dr. Hasan Sadikin Bandung.

Subjek penelitian adalah penderita karsinoma nasofaring WHO tipe III stadium I dan II tanpa pembesaran kelenjar getah bening yang belum pernah mendapatkan radioterapi, kemoterapi, ataupun pembedahan di daerah leher. Faktor lain yang dapat menyebabkan aterosklerosis seperti hipertensi menurut Joint National Commitee VII, hiperkolesterolemia, hipertrigliserida, dan diabetes melitus menurut American Association of Clinical Endocrinologist 2003 dieksklusikan terlebih dulu dengan pemeriksaan laboratorium darah.

Subjek penelitian praradioterapi dilakukan pemeriksaan tekanan darah dan selanjutnya penderita dalam keadaan puasa selama 8-10 jam dilakukan pengambilan darah yang pertama dan kemudian penderita dipersilahkan makan dan minum untuk pemeriksaan darah yang kedua (2 jam setelah makan dan minum). Pemeriksaan darah dilakukan untuk mengetahui faktor risiko lain yang dapat menyebabkan aterosklerosis. Bila penderita tidak termasuk ke dalam faktor risiko tersebut, maka penderita termasuk ke dalam subjek penelitian. Setelah pemeriksaan darah, dilanjutkan dengan pemeriksaan ultrasonografi (USG) ke-1 di Departemen Radiologi RSHS sebelum dilakukan radioterapi. Bila penderita telah mendapat radioterapi sampai mencapai dosis total sekitar 6.600-7.000 cGy maka dilanjutkan pemeriksaan USG ke-2. Pemeriksaan USG ke-3 dilakukan 10 minggu setelah radioterapi.

Data dianalisis dengan uji Fischer (analisis varian data berpasangan) dan uji t berpasangan. Kemaknaan ditentukan berdasarkan nilai $\mathrm{p}<0,05$.

\section{Hasil}

Subjek penelitian terutama laki-laki 30-49 tahun, stadium II, dan mendapat dosis total radioterapi $6.600 \mathrm{cGy}$ (Tabel 1).

Pada semua subjek penelitian, didapatkan IMT rata-rata arteri karotis komunis kanan pra dan pascaradioterapi eksternal sebesar 0,64 $\mathrm{mm}$, dan 10 minggu pascaradioterapi eksternal sebesar $0,74 \mathrm{~mm}$. Berdasarkan selisih IMT 10 minggu pascaradioterapi eksternal dengan IMT praradioterapi didapatkan peningkatan sangat bermakna $(\mathrm{p}<0,001)$ pada IMT akibat radioterapi eksternal sebesar $0,108 \mathrm{~mm}$ atau meningkat $17 \%$ pada arteri karotis komunis kanan (Tabel 2).

Pada arteri karotis komunis kiri didapatkan IMT rata-rata pra dan pascaradioterapi eksternal sebesar 0,64 $\mathrm{mm}$ dan 10 minggu pascaradioterapi eksternal $0,73 \mathrm{~mm}$. Berdasarkan selisih IMT 10 minggu pascaradioterapi eksternal dan IMT praradioterapi didapatkan peningkatan yang sangat bermakna $(p<0,001)$ akibat radioterapi eksternal sebesar $0,09 \mathrm{~mm}$ atau meningkat $14,9 \%$ pada arteri karotis komunis kiri. Perbandingan IMT ( $\triangle$ IMT) antara arteri karotis komunis kanan dan karotis komunis kiri menunjukkan hubungan yang tidak bermakna $(\mathrm{p}=0,679)$ (Tabel 2).

Pada arteri karotis komunis kanan dan kiri terlihat hubungan sangat bermakna $(p<0,001)$ pemberian radioterapi eksternal dan nilai IMT 10 minggu pascaradioterapi eksternal. Hal ini menunjukkan bahwa radioterapi eksternal mulai mempunyai pengaruh pada dinding pembuluh darah 10 minggu pascaradioterapi eksternal.

Nilai diameter lumen arteri karotis komunis kanan rata-rata praradioterapi eksternal 7,992 $\mathrm{mm}$, pascaradioterapi eksternal 7,996 $\mathrm{mm}$ dan 10 minggu pascaradioterapi eksternal 7,612 $\mathrm{mm}$. Berdasarkan selisih lumen praradioterapi dan 10 minggu pascaradioterapi terdapat pengurangan yang sangat bermakna $(p<0,001)$ pada lumen arteri sebesar $0,384 \mathrm{~mm}$ atau menurun $4,8 \%$ pada arteri karotis komunis kanan (Tabel 3).

Pada arteri karotis komunis kiri didapatkan nilai lumen rata-rata praradioterapi eksternal $7,748 \mathrm{~mm}$, pascaradioterapi eksternal 7,752 $\mathrm{mm}$, dan 10 minggu pascaradioterapi eksternal 7,412 $\mathrm{mm}$. Berdasarkan selisih lumen praradioterapi eksternal dengan 10 minggu pascaradioterapi eksternal, maka didapatkan pengurangan yang sangat bermakna $(p<0,001)$ pada lumen arteri sebesar $0,342 \mathrm{~mm}$ atau menurun $4,4 \%$ pada arteri karotis komunis kiri. Perbandingan ukuran lumen

Tabel 1 Karakteristik Subjek Penelitian ( $n=$ 25)

\begin{tabular}{lc}
\hline \multicolumn{1}{c}{ Karakteristik } & Jumlah \\
\hline Jenis kelamin & 16 \\
Laki-laki & 9 \\
Perempuan & \\
Usia (tahun) & 2 \\
$<30$ & 6 \\
$30-39$ & 15 \\
$40-49$ & 2 \\
$\geq 50$ & $40,52(6,04)$ \\
X (SB) & $25-50$ \\
Rentang & \\
Stadium & 3 \\
I & 22 \\
II & \\
Dosis total radioterapi (cGy) & 22 \\
6.600 & 2 \\
6.800 & 1 \\
7.000 &
\end{tabular}


Tabel 2 Hubungan Radioterapi Eksternal dengan Nilai IMT Arteri Karotis Komunis berdasarkan Waktu Pengamatan ( $n=25)$

\begin{tabular}{|c|c|c|c|c|}
\hline \multirow[b]{2}{*}{ Arteri } & \multicolumn{3}{|c|}{ IMT (mm) } & \multirow[b]{2}{*}{ Kemaknaan } \\
\hline & Praradioterapi & Pascaradioterapi & $\begin{array}{c}10 \text { Minggu } \\
\text { Pascaradioterapi }\end{array}$ & \\
\hline \multicolumn{5}{|l|}{ Karotis komunis } \\
\hline $\mathrm{X}(\mathrm{SD})$ & $0,64(0,057)$ & & & $\mathrm{F}=59,108$ \\
\hline Rentang & $0,5-0,7$ & & & $\mathrm{p}<0,001$ \\
\hline \multirow[t]{2}{*}{ Perbandingan* } & Pra $x$ Pasca: $p=1,0$ & & $\begin{array}{l}\text { Pasca } \times 10 \\
\text { minggu:p }<0,001\end{array}$ & \\
\hline & $\begin{array}{l}\text { Pra } x 10 \\
\text { minggu:p }<0,001\end{array}$ & & $\begin{array}{l}\Delta=0,1 \mathrm{~mm}, \\
\text { meningkat } 17 \% \\
(\mathrm{p}<0,001\end{array}$ & \\
\hline \multicolumn{5}{|l|}{ Karotis komunis kiri } \\
\hline$X(S D)$ & $0,64(0,057)$ & $0,64(0,057)$ & $0,73(0,054)$ & $\mathrm{F}=42,892$ \\
\hline Rentang & $0,5-0,7$ & $0,5-0,7$ & $0,7-0,9$ & $\mathrm{P}<0,001$ \\
\hline \multirow[t]{2}{*}{ Perbandingan* } & Pra $x$ Pasca: $p=1,0$ & & $\begin{array}{l}\text { Pasca } x 10 \\
\text { minggu:p }<0,001\end{array}$ & \\
\hline & $\begin{array}{l}\text { Pra } x 10 \\
\text { minggu: } p<0,001\end{array}$ & & $\begin{array}{l}\Delta=0,09 \mathrm{~mm}, \\
\text { meningkat } 14,9 \% \\
(\mathrm{p}<0,001)\end{array}$ & \\
\hline
\end{tabular}

Keterangan: F=uji Fischer (analisis varians data berpasangan), $\Delta=$ selisih IMT 10 minggu dan IMT praradioterapi, *berdasarkan uji t berpasangan, IMT=intima media thickness

Tabel 3 Hubungan Radioterapi Eksternal dengan Diameter Lumen Arteri Karotis Komunis berdasarkan Waktu Pengamatan

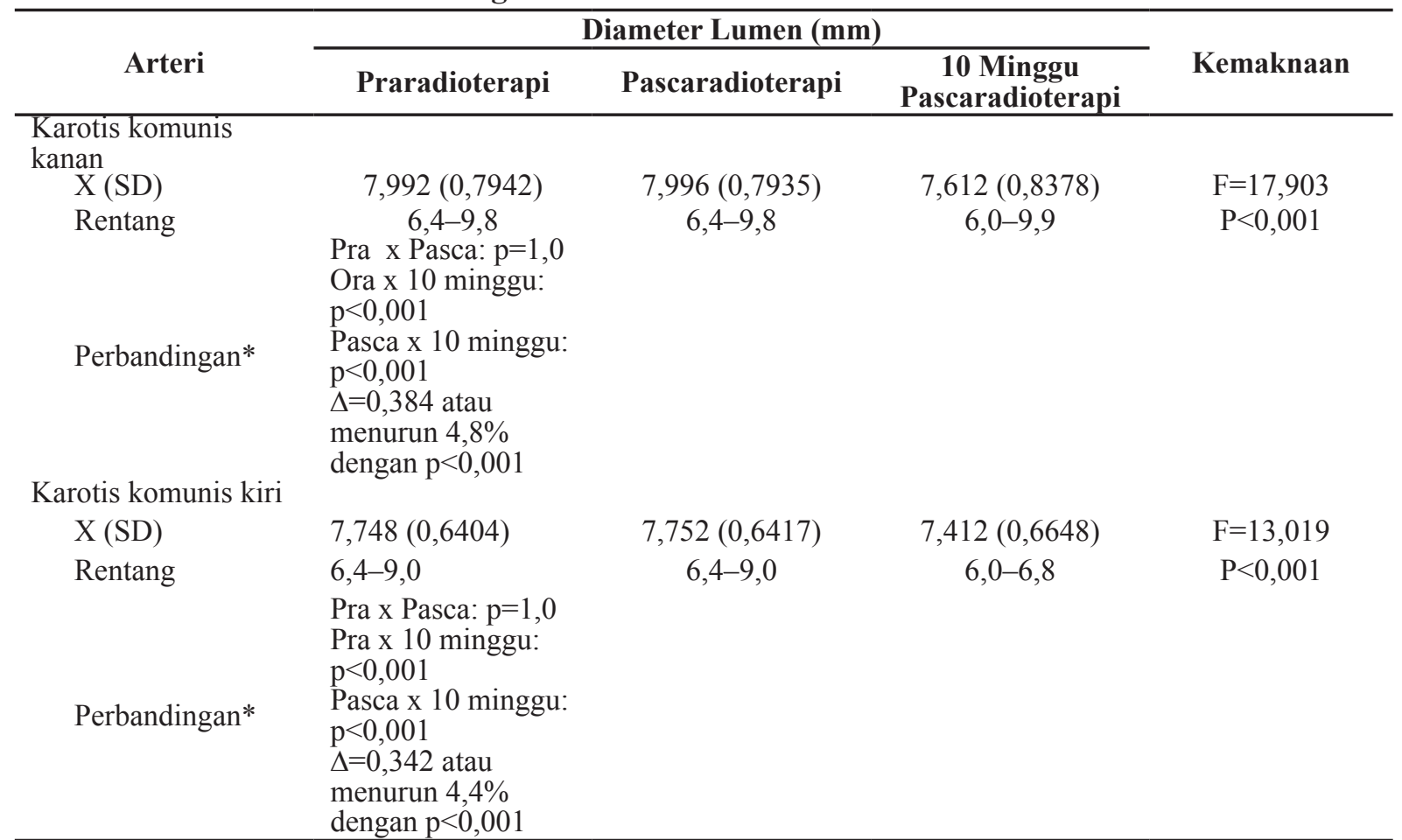

Keterangan: $\mathrm{F}=$ uji Fischer (analisis varian data berpasangan), $\Delta=$ selisih lumen 10 minggu pascaradioterapi dengan lumen praradioterapi, * berdasarkan uji t berpasangan

( $\Delta$ lumen) antara arteri karotis komunis kanan dan karotis komunis kiri menunjukkan hubungan yang tidak bermakna $(p=0,744)$.

Pada arteri karotis komunis kanan dan kiri 
Ferryan Sofyan: Ketebalan Tunika Intima dan Media Arteri Karotis Komunis pada Karsinoma Nasofaring

Tabel 4 Hubungan antara Dosis Total Radioterapi Eksternal dan Aterosklerosis Arteri Karotis Komunis Kanan

\begin{tabular}{lcccc}
\hline \multirow{2}{*}{ Dosis Total (cGy) } & \multicolumn{2}{c}{ IMT Pascaradioterapi } & \multicolumn{2}{c}{$\mathbf{1 0}$ Minggu Pascaradioterapi } \\
\cline { 2 - 5 } & $<\mathbf{0 , 8} \mathbf{~ m m}$ & $\mathbf{0 0 , 8} \mathbf{~ m m}$ & $<\mathbf{0 , 8} \mathbf{~ m m}$ & $\mathbf{0 0 , 8} \mathbf{~ m m}$ \\
\hline 6.600 & 22 & 0 & 13 & 9 \\
6.800 & 2 & 0 & 1 & 1 \\
7.000 & 1 & 0 & 1 & 0 \\
Total penderita (n) & 25 & 0 & 15 & 10 \\
\hline
\end{tabular}

Keterangan: nilai $\mathrm{p}$ dihitung berdasarkan eksak Fischer $\left(\mathrm{P}_{\mathrm{EF}}=1,0\right)$

terdapat hubungan sangat bermakna $(\mathrm{p}<0,001)$; hubungan radioterapi dengan ukuran lumen 10 minggu pascaradioterapi eksternal menunjukkan hasil yang sangat bermakna $(p<0,001)$. Hal ini menunjukkan bahwa radioterapi eksternal mulai berpengaruh pada lumen pembuluh darah 10 minggu pascaradioterapi eksternal (Tabel 3).

Aterosklerosis belum terjadi pada penderita pascaradioterapi eksternal, tetapi sebaliknya pada penderita yang telah melewati $10 \mathrm{minggu}$ selesai radioterapi eksternal, terdapat $10(10 / 25)$ penderita yang mengalami peningkatan IMT $\geq 0,8$ $\mathrm{mm}$ atau telah terjadi aterosklerosis arteri karotis kanan. Analisis statistik dengan uji eksak Fisher didapatkan nilai $\mathrm{p}=1,0$ atau tidak ada hubungan yang bermakna antara dosis total radioterapi eksternal dan terjadi aterosklerosis arteri karotis komunis kanan (Tabel 4).

Aterosklerosis belum terjadi pada penderita pascaradioterapi eksternal, tetapi sebaliknya pada penderita yang telah melewati 10 minggu selesai radioterapi, terdapat $6(6 / 25)$ penderita yang mengalami peningkatan IMT $\geq 0,8 \mathrm{~mm}$ atau telah terjadi aterosklerosis arteri karotis kiri. Analisis statistik uji eksak Fisher didapatkan nilai $\mathrm{p}=1,0$ atau tidak terdapat hubungan bermakna antara dosis total radioterapi eksternal dan aterosklerosis arteri karotis komunis kiri (Tabel 5).

\section{Pembahasan}

Penelitian menunjukkan penderita karsinoma nasofaring lebih banyak ditemukan pada laki- laki bila dibandingkan dengan wanita (2:1). Hal yang sama juga dilaporkan oleh Cannon dkk. ${ }^{14}$ yang menyatakan bahwa angka kejadian karsinoma nasofaring pada pria dua kali lebih banyak bila dibandingkan dengan wanita. Dari semua penelitian yang ada, menunjukkan bahwa laki-laki juga lebih sering menderita karsinoma nasofaring dibandingkan dengan wanita, hal ini diduga karena laki-laki lebih sering terpapar zat karsinogen antara lain tembakau, alkohol, dan asap rokok.

Hasil penelitian juga menunjukkan bahwa penderita karsinoma nasofaring diderita terutama pada dekade ke-4-5. Hasil penelitian ini sesuai dengan penelitian Cannon dkk. ${ }^{14}$ yang menyatakan karsinoma nasofaring terutama diderita pada usia lebih dari 30 tahun.

Pada penelitian, semua penderita karsinoma nasofaring yang menjadi subjek dalam stadium I dan II. Stadium II lebih banyak terjadi daripada stadium I, keadaan ini sesuai dengan penelitian Ping dkk. ${ }^{15}$ Hal ini disebabkan karena terdapat gejala klinis yang muncul akibat perkembangan stadium penyakit.

Pada penelitian ini, dosis total radioterapi eksternal yang diberikan pada stadium I dan II sebesar 6.600-7.000 cGy. Keadaan ini sesuai dengan penelitian Khademi dkk. ${ }^{16}$ bahwa dosis radioterapi untuk tumor primer mendapat 6.500 -7.500 cGy dan 6.500-7.000 cGy untuk kelenjar getah bening yang terlibat.

Hasil pengukuran ketebalan dinding intima media arteri karotis komunis kanan dan kiri pada penderita karsinoma nasofaring yang telah

Tabel 5 Hubungan antara Dosis Total Radioterapi Eksternal dan Aterosklerosis Arteri Karotis Komunis Kiri

\begin{tabular}{lcccc}
\hline \multirow{2}{*}{ Dosis Total (cGy) } & \multicolumn{2}{c}{ IMT Pascaradioterapi } & \multicolumn{2}{c}{$\mathbf{1 0}$ Minggu Pascaradioterapi } \\
\cline { 2 - 5 } & $<\mathbf{0 , 8} \mathbf{~ m m}$ & $\mathbf{0 0 , 8} \mathbf{~ m m}$ & $<\mathbf{0 , 8} \mathbf{~ m m}$ & $\geq \mathbf{0 , 8} \mathbf{~ m m}$ \\
\hline 6.600 & 22 & 0 & 17 & 5 \\
6.800 & 2 & 0 & 1 & 1 \\
7.000 & 1 & 0 & 1 & 0 \\
Total penderita (n) & 25 & 0 & 19 & 6 \\
\hline
\end{tabular}

Keteterangan: nilai $\mathrm{p}$ dihitung berdasarkan eksak Fisher $\left(\mathrm{P}_{\mathrm{EF}}=1,0\right)$ 
melewati 10 minggu pascaradioterapi eksternal menunjukkan peningkatan ketebalan dinding intima media pembuluh darah bila dibandingkan dengan IMT pra dan pascaradioterapi eksternal. Keadaan ini memperlihatkan bahwa radioterapi eksternal menyebabkan peningkatan ketebalan dinding intima media sebesar $0,108 \mathrm{~mm}$ atau meningkat $17 \%$ pada arteri karotis komunis kanan dan 0,092 mm atau meningkat $14,9 \%$ pada arteri karotis kiri dalam jangka waktu 10 minggu. Hal ini hampir sama dengan penelitian Basiratnia dkk. ${ }^{17}$ yang menilai perubahan arteri karotis penderita dengan keganasan limfoma Hodgkin setelah radioterapi eksternal dalam jangka waktu 5 tahun. Pada penelitian tersebut didapatkan IMT pada kelompok yang dilakukan radioterapi eksternal lebih tinggi bila dibandingkan dengan kelompok tidak dilakukan radioterapi eksternal. Pada penelitian ini, data IMT praradioterapi eksternal dibandingkan dengan IMT pasca dan 10 minggu pascaradioterapi eksternal, sedangkan Basiratnia dkk. ${ }^{17}$ tidak memiliki data awal IMT praradioterapi eksternal dan memiliki waktu observasi pascaradioterapi eksternal yang lama sekitar 5 tahun, sehingga didapat hasil bermakna terhadap terbentuknya aterosklerosis dan plak ukuran $<2 \mathrm{~mm}$. Dari kedua penelitian tersebut dapat disimpulkan bahwa terjadi peningkatan ketebalan dinding intima media pembuluh darah akibat radioterapi eksternal.

Hubungan peningkatan ketebalan dinding intima media (IMT) dengan diameter lumen arteri karotis komunis pada penelitian ini yaitu peningkatan IMT menyebabkan pengurangan diameter lumen pembuluh darah. Keadaan ini sesuai dengan penelitian Gianicolo dkk. ${ }^{6}$ yang menyatakan bahwa terjadi peningkatan ketebalan lapisan intima media pada arteri karotis komunis pada penderita yang telah mendapat radioterapi di leher 2,9 tahun lalu. Pengurangan diameter lumen akan terlihat bila terjadi penyempitan $>40 \%$.

Hubungan dosis total radioterapi dengan aterosklerosis arteri karotis komunis kanan dan kiri pada penelitian ini tidak menunjukkan hasil yang bermakna, walaupun terjadi peningkatan IMT akibat radioterapi. Hal ini terjadi karena variasi nilai IMT praradioterapi pada subjek penelitian dengan rentang nilai $0,5-0,7 \mathrm{~mm}$, sehingga untuk terjadinya aterosklerosis dengan peningkatan $0,09-0,1 \mathrm{~mm}$ sesudah 10 minggu pascaradioterapi eksternal tidak menunjukkan hasil bermakna. Hasil tidak bermakna kemungkinan disebabkan waktu observasi pascaradioterapi eksternal yang dibatasi hanya 10 minggu. Simpulan, radioterapi eksternal menunjukkan ketebalan tunika media dan pengurangan diameter lumen arteri karotis komunis pada penderita karsinoma nasofaring.

\section{Daftar Pustaka}

1. Brennan B. Nasopharyngeal carcinoma. Orphanet J Rare Dis. 2006; 1:23.

2. Tabuchi K, Nakayama M, Nishimura B, Hayashi K, Hara A. Early detection of nasopharyngeal carcinoma. Int J Otolaryngol. 2011;638058.

3. Laporan tahunan kunjungan penderita di bagian THT-KL FKUI/RSCM tahun 19952000.

4. Laporan tahunan kunjungan penderita di bagian THT-KL FK Unpad/RS Dr. Hasan Sadikin Bandung tahun 2001-2005.

5. Underbrink M, Anna P. The principle of radiation oncology. Grand Rounds presentation, UTMB. Departement of Otolaryngology [diunduh 20 Juni 2008]. Tersedia dari: http://www.utmb.edu/otoref/ grnds/radiation-oncology.org.

6. Gianicolo ME, Gianicolo EA, Tramacere F, Andreassi MG, Portaluri M. Effects of external irradiation of the neck region on intima media thickness of the common carotid artery. Cardiovasc Ultrasound 2010;8:8.

7. Soloviev AI, Tishkin SM, Parshikov AV, Ivanova IV, Goncharov EV, Gurney AM. Mechanisms of endothelial dysfunction after ionized radiation: selective impairment of the nitric oxide component of endotheliumdependent vasodilation. $\mathrm{Br} \mathrm{J}$ Pharmacol. 2003;138(5):837-44.

8. Kaushal S, Shake JG, Yuh DD. Mycotic innominate artery pseudoaneurysm presenting as an embolic stroke. J Thorac Cardiovasc Surg. 2005;129(4):945-6.

9. Penagaricano JA, Linskey ME, Ratanatharathorn V. Accelerated cerebral vasculopathy after radiation therapy to the brain. Neurol India. 2004;52(4):482-6.

10. Perhimpunan Onkologi Radiasi Indonesia. Standar pelayanan radioterapi kanker nasofaring di subbagian Radioterapi RSHS. Bandung: Departemen Radiologi RSHS; 2002.

11. Overgaard J, Horsman MR. Overcoming hypoxic cell radio-resistance. Dalam: Steel GG, penyunting. Basic clinical radiobiology for radiation oncologists. Edisi ke-2. London. Edward Arnold; 1993. hlm. 141-51.

12. Friedlander AH, Freymiller EG. Detection of radiation-accelerated atherosclerosis of the carotid artery by panoramic radiography. A new opportunity for dentists. J Am Dent Assoc. 2003;134(10):1361-5.

13. O'Leary DH, Polak JF. Intima-media thickness: a tool for atherosclerosis imaging and event prediction. Am J Cardiol. 
2002;90(10C):18-21L

14. Cannon T, Zanation AM, Lai V, Weissler MC. Nasopharyngeal carcinoma in young patients: a systematic review of racial demographics. Laryngoscope. 2006;116(6): 1021-6.

15. Mao YP, Liang SB, Liu LZ, Chen Y, Sun $\mathrm{Y}$, Tang LL, dkk. The $\mathrm{N}$ staging system in nasopharyngeal carcinoma with radiation therapy oncology group guidelines for lymph node levels based on magnetic resonance imaging. Clin Cancer Res.
2008;14(22):7497-503.

16. Khademi B, Mahmoodi J, Omidvari S, Mohammadianpanah M. Treatment results of nasopharyngeal carcinoma: a 15-year single institutional experience. J Egypt Natl Canc Inst. 2006;18(2):147-55.

17. Basiratnia R, Gokizadeh A, Hekmatnia A, Fani I. Ultrasonographic carotid changes in patients with hodgkin's disease after radiotherapy: a historical cohort study. Iran J Radiol. 2006;4(1):17-20. 